\title{
KAJIAN HUBUNGAN KEBIJAKAN BAURANPEMASARANDAN VOLUME PENJUALAN GULA MERAH (SAKA) RAKYAT DI KABUPATEN TANAH DATAR SUMATERA BARAT
}

\section{STUDY OF RELATION BETWEEN MARKETING MIX AND SELLING VOLUME OF FARMER BROWN SUGAR (SAKA) IN TANAH DATAR REGENCY WEST SUMATERA}

\author{
Rina Sari dan Nofialdi \\ Dosen Program Studi Agribisnis Fakultas Pertanian Universitas Andalas \\ Email: rinasari@gmail.com
}

\begin{abstract}
Brown sugar (saka) is one of alternative goods to fill sugar demand in Indonesia. This product is mainly produced by local agroindustries that disperse in many regions, one of the location is in Tanah Datar Regency. The aims of this study are to describe the marketing mix and to analyze the relation between marketing mix and selling volume of brown sugar in Tanah Datar Regency. Variables of this research are 4P of marketing mix and selling volume. The data is collected from farmer who produced traditionally, that spread in three district, then using quantitative analyze. The result of this research shows that product is molded by piece of coconut shell (diameter: 3-5 cm), the color is brown, reddish and yellowish, the selling price about $R p 10.000-15.000 / \mathrm{Kg}$, and distributted through collecting traders or directly sold in market, and also have no promotion yet. The result of Chi Square analyze shows that there are relation between selling price variable with product variable, whereas place/ distribution variable is not.
\end{abstract}

Keywords : brown sugar, agroindustry, marketing mix

\section{PENDAHULUAN}

Keragaan perkembangan volume impor gula Indonesia tahun 1980-2013 cenderung meningkat pertahunnya. Impor gula Indonesia pada tahun 1981 sebesar 720,95 ton dan meningkat hingga sebesar 1.606.517 ton pada tahun 2013. Adapun volume impor tertinggi Indonesia terjadi pada tahun 2007 dengan volume impor mencapai 2.972.788 ton gula (Kementerian Pertanian, 2014).

Gula merah merupakan salah satu alternatif dalam memenuhi kebutuhan gula di Indonesia. Gula merah diproduksi dengan menggunakan bahan baku dari kelompok tanaman palem (aren, lontar, nipah dan kelapa) dan tebu. Saat ini usaha gula merah tebu diproduksi dengan teknik pengolahan yang sangat sederhana maupun secara mekanik, dan dapat diusahakan dalam skala rumah tangga. Banyak penelitian tentang industri gula merah baik berbahan baku kelapa maupun menunjukan bahwa usaha gula merah dalam skala rumah tangga layak untuk diusahakan. Penelitian oleh Margono, dkk (2014) menunjukkan bahwa Nilai 
Revenue cost ratio industri gula merah kelapa di Wonosobo rata-rata sebesar 2,4 sehingga usaha ini layak dijalankan. Sementara penelitian, penelitian kencana, dkk, (2012) menyimpulkan bahwa secara keseluruhan, pengrajin gula merah aren di Bengkulu tidak mengalami resiko terhadap nira yang diperoleh, nira yang diproses, produksi, dan harga yang diterima baik pada musim hujan dan musim kemarau. Informasi ini menunjukkan bahwa pengembangan industri gula merah layak untuk dikembangkan lebih lanjut. Mengembangkan agroindustri rakyat yang bersifat tradisional tersebut perlu dilakukan strategi pemasaran yang tepat agar mampu meningkatkan volume penjualan dan berkembang dengan baik.

Permasalahan memasarkan produk pertanian, antara lain: (a) kesinambungan produksi; (b) panjangnya saluran pemasaran; (c) kurang memadainya pasar; (d) kurang tersedianya informasi pasar; (e) rendahnya kemampuan tawar-menawar; (f) berfluktuasinya harga; (g) rendahnya kualitas produksi; (h) kurang jelasnya jaringan pemasaran; dan (i) rendahnya kualitas sumberdaya manusia (Syahza, 2005). Strategi pemasaran adalah cara untuk mampu mencapai keuntungan dan keunggulan bersaing. Strategi pemasaran terkait dengan variabel-variabel seperti segmentasi pasar, identifikasi pasar sasaran, positioning, elemen bauran pemasaran dan biaya bauran pemasaran. Bauran pemasaran (marketing mix) merupakan seperangkat alat pemasaran khusus yang digunakan perusahaan, yang terdiri dari produk, harga, promosi, dan tempat atau distribusi. Untuk itu, perusahaan harus berusaha menemukan strategi yang tepat untuk bertahan dan dapat memenuhi tujuan perusahaan berupa laba yang maksimal dengan meningkatkan volume penjualan (Kotler and Armstrong, 2014).

Kabupaten Tanah Datar memiliki 205 unit usaha pengolahan hasil tebu tradisional yang bergerak di usaha gula merah. Seiring dengan terus berkembangnya teknologi, industri kecil semakin terancam keberadaannya. Hal ini dikarenakan banyak muncul pabrik yang menggunakan teknologi mekanik sehingga persaingan industri gula merah semakin ketat yang akan berdampak pada volume penjualan.

Di sisi pemasaran, pelaku usaha atau produsen gula merah (saka) juga menghadapi beberapa hal berkaitan dengan volume penjualan dan pengembangan usahanya. Perubahan gaya hidup masyarakat dalam mengkonsumsi gula akan mempengaruhi perkembangan industri gula merah rakyat. Sebagian orang mempercayai bahwa gula merah lebih sehat dan lebih murah dibandingkan gula pasir rafinasi buatan pabrik. Demikian juga dalam hal kebiasaan masyarakat menggunakan gula merah untuk makanan-makanan tradisional seperti kolak, kareh-kareh, pinyaram, dan lain-lain, tidak dapat digantikan begitu saja dengan gula pasir. Perilaku masyarakat seperti itu merupakan peluang bagi pengembangan industri gula merah rakyat sebagai bagian dari agroindustri tebu di Kabupaten Tanah Datar. Hal ini menuntut usaha rakyat pembuatan gula merah membuat strategi pemasaran yang matang, 
terutama dalam hal bauran pemasaran (marketing mix) yang mencakup 4P (product, price, place, and promotion), agar dapat bersaing dengan produk sejenis.

Kebijakan bauran pemasaran yang dilaksanakan oleh produsen akan mempengaruhi perilaku konsumsi masyarakat yang akan berpengaruh terhadap naik turunnya volume penjualan. Produsen akan selalu menghadapi situasi dinamis di tengah persaingan dan kemajuan teknologi. Untuk itu produsen harus mampu meninjau ulang dan mengelola kebijakan bauran pemasarannya sehingga dapat meningkatkan volume penjualan.

Berdasarkan latar belakang di atas, penelitian tentang hubungan bauran pemasaran dan volume penjualan pada industri pengolahan hasil tebu tradisional, khususnya pembuatan gula merah, di Kabupaten Tanah Datar perlu dilakukan. Pertanyaan yang ingin dijawab dengan penelitian ini adalah bagaimana gambaran usaha dan bauran pemasaran yang dilaksanakan serta bagaimana hubungan antara bauran pemasaran tersebut dengan volume penjualan yang terjadi. Dengan demikian, tujuan penelitian ini adalah untuk menjelaskan bauran pemasaran dan menganalisis hubugan bauran pemasaran dan volume penjualan gula merah rakyat di Kabupaten Tanah Datar.

\section{METODE PENELITIAN}

Metode penelitian yang digunakan dalam penelitian ini adalah metode survei, dengan populasi adalah produsen gula merah tradisional di Kabupaten Tanah Datar. Metode penarikan sampel yang dipilih adalah non-probability sampling dengan accidental sampling. Sampel yang digunakan sebagai responden dalam penelitian ini adalah produsen gula merah tradisional, berjumlah 30 orang responden.

Data dalam penelitian ini terdiri dari data primer yang diperoleh dari pengolah tradisional sekaligus penjual gula merah di Kabupaten Tanah Datar dan data sekunder. Variabel penelitian terdiri dari variabel bebas yaitu bauran pemasaran (marketing mix) yang terdiri dari 4 variabel, yaitu produk, harga, distribusi/tempat dan promosi. Variabel terikat dalam penelitian ini adalah volume penjualan dari produk gula merah. Pengolahan data dilakukan melalui beberapa tahapan, yaitu: editing, coding, perhitungan data, dan analisis data dilakukan secara kuantitatif bertingkat yaitu univariat dan bivariat.

\section{HASIL DAN PEMBAHASAN}

\section{Gambaran Umum Lokasi Penelitian, Responden dan Usaha}

Kabupaten Tanah Datar adalah salah satu kabupaten di Provinsi Sumatera Barat yang dikenal sebagai “Luhak Nan Tuo" terletak pada $00^{\circ} 17^{\prime}$ sampai dengan $00^{\circ} 39^{\prime}$ LS dan $100^{\circ} 19^{\prime}$ sampai dengan $100^{\circ} 51^{\prime}$ BT. Kabupaten 
Tanah Datar memiliki luas wilayah 1336,00 Km², terdiri dari 14 kecamatan dan 75 nagari. Penelitian dilakukan di tiga kecamatan, yakni Kecamatan Salimpaung, Kecamatan X Koto dan Kecamatan Tanjung Baru.

Secara geografis wilayah Kabupaten Tanah Datar berada di sekitar kaki Gunung Merapi dan Gunung Sago, dan terdapat 25 sungai. Lokasi penelitian adalah kecamatan dengan letak ketinggian antara 750 sampai dengan 1000 meter di atas permukaan laut, dan memiliki rata-rata curah hujan $147 \mathrm{~mm} /$ bulan dengan rata-rata hari hujan sebanyak 12 hari/bulan. Kabupaten Tanah Datar memiliki panjang jalan nasional 39,10 Km, panjang jalan provinsi $138,50 \mathrm{Km}$ dan panjang jalan kabupaten 1408,8 Km (Badan Pusat Statistik, 2015).

Tabel 1 dan 2 menginformasikan profil responden dan profil usaha gula merah yang digeluti rumah tangga.

Tabel 1. Profil Responden

\begin{tabular}{|c|c|c|c|}
\hline No & Karakteristik & Jumlah & Persentase $(\%)$ \\
\hline \multirow{3}{*}{1} & Jenis Kelamin & & \\
\hline & Laki-laki & 9 & 30,00 \\
\hline & Perempuan & 21 & 70,00 \\
\hline \multirow{6}{*}{2} & Umur (Tahun) & & \\
\hline & $20-30$ & 3 & 10,00 \\
\hline & $31-40$ & 4 & 13,33 \\
\hline & $41-50$ & 7 & 23,33 \\
\hline & $51-60$ & 8 & 26,67 \\
\hline & $<61$ & 8 & 26,67 \\
\hline \multirow{6}{*}{3} & Pendidikan & & \\
\hline & SD & 21 & 70,00 \\
\hline & SMP & 6 & 20,00 \\
\hline & SMA & 2 & 6,67 \\
\hline & Diploma & 0 & 0,00 \\
\hline & Sarjana & 1 & 3,33 \\
\hline \multirow{4}{*}{4} & Pekerjaan Lain & & \\
\hline & Petani & 17 & 56,67 \\
\hline & Pedagang & 1 & 3,33 \\
\hline & Tidak ada & 12 & 40,00 \\
\hline \multirow{6}{*}{5} & Pendapatan/ Bulan & & \\
\hline & $>\operatorname{Rp} 500.000$ & 0 & 0,00 \\
\hline & Rp 500.000 - Rp1.499.999 & 2 & 6,67 \\
\hline & Rp 1.500.000 - Rp2.499.999 & 14 & 46,67 \\
\hline & Rp 2.500.000 - Rp3.499.999 & 11 & 0,00 \\
\hline & $<\operatorname{Rp} 3.500 .000$ & 3 & 10,00 \\
\hline
\end{tabular}

4 | Rina Sari dan Nofialdi, Kajian Hubungan Kebijakan Bauran Pemasaran 
Data pada tabel 1 ini menginformasikan perempuan juga menguasai proses pembuatan gula merah yang diusahakan, meskipun data ini tidak menunjukkan status kepemilikan usaha. Tingkat pendidikan yang rendah dari responden juga mencari penciri dari industri kecil yang diusahakan bahwa usaha pengolahan gula merah tidak membutuhkan tingkat pendidikan yang tinggi. Data pada Tabel 1 juga menginformasikan bahwa pengolahan gula merah bukan merupakan pekerjaan satu-satunya yang digeluti rumah tangga.

Tabel 2. Profil Usaha

\begin{tabular}{|c|c|c|c|}
\hline No & Karakteristik & Jumlah & Persentase (\%) \\
\hline \multirow{6}{*}{1} & Tahun Berdiri & & \\
\hline & $<1975$ & 1 & 3,33 \\
\hline & $1975-1985$ & 9 & 30,00 \\
\hline & $1986-1995$ & 10 & 33,33 \\
\hline & $1996-2005$ & 9 & 30,00 \\
\hline & $2006-2015$ & 1 & 3,33 \\
\hline \multirow{15}{*}{2} & Skala Usaha & & \\
\hline & Jumlah Tenaga Kerja & & \\
\hline & 1-4 orang & 30 & 100,00 \\
\hline & 5-19 orang & 0 & 0,00 \\
\hline & 20-99 orang & 0 & 0,00 \\
\hline & $>100$ orang & 0 & 0,00 \\
\hline & Modal Investasi & & \\
\hline & $<\operatorname{Rp} 14.999 .999$ & 2 & 6,67 \\
\hline & $\pm \operatorname{Rp} 15.000 .000- \pm \operatorname{Rp} 19.999 .999$ & 3 & 10,00 \\
\hline & $\pm \operatorname{Rp} 20.000 .000- \pm \operatorname{Rp} 29.999 .999$ & 23 & 76,67 \\
\hline & $\pm \operatorname{Rp} 30.000 .000- \pm \operatorname{Rp} 40.000 .000$ & 2 & 6,67 \\
\hline & Modal Operasional & & \\
\hline & $<\operatorname{Rp} 99.999$ & 8 & 26,67 \\
\hline & $>\operatorname{Rp} 100.000$ & 11 & 36,67 \\
\hline & Tidak ada keterangan & 11 & 36,67 \\
\hline \multirow{4}{*}{3} & Sumber Bahan Baku & & \\
\hline & Lahan Sendiri & 22 & 73,33 \\
\hline & Orang lain & 1 & 3,33 \\
\hline & Keduanya & 7 & 23,33 \\
\hline \multirow{4}{*}{4} & Spesifikasi Bahan Baku & & \\
\hline & Berdasarkan Ukuran & 8 & 26,67 \\
\hline & Berdasarkan Umur & 21 & 70,00 \\
\hline & Keduanya & 1 & 3,33 \\
\hline \multirow{3}{*}{5} & Jumlah Produksi/ Kancah & & \\
\hline & $10 \mathrm{Kg}-15 \mathrm{Kg}$ & 19 & 63,33 \\
\hline & $15,1 \mathrm{Kg}-20 \mathrm{Kg}$ & 11 & 36,67 \\
\hline
\end{tabular}


Tabel 2 menginformasikan profil usaha gula merah yang ada di lokasi penelitian. Data ini menunjukkan bahwa usaha gula merah telah diusahakan lebih dari 10 tahun. Dilihat dari skala usahanya, usaha gula merah ini dapat dikategorikan usaha kecil dengan jumlah tenaga kerja antara 1-4 orang. Kecilnya skala usaha gula merah ini juga dapat dilihat dari besanya biaya operasional yang digunakan untuk memproduksi gula merah. Biaya operational yang diperlukan hanya sekitar Rp. 100.000 untuk sekali proses produksi. Lebih lanjut, jumlah produksi gula merah yang dihasilkan juga relatif kecil yaitu $10-15 \mathrm{~kg}$ per proses produksi.

Dilihat dari teknologi yang digunakan, semua pengrajin gula merah di lokasi penelitian masih menggunakan teknologi yang sederhana. Oleh sebab itu, biaya investasi yang dikeluarkan oleh pengrajin juga relatif kecil. Disamping itu, sumber bahan baku utama gula merah berasal dari hasil lahan yang dimiliki oleh rumah tangga meskipun ada yang memperoleh dari orang lain dengan jumlah yang tidak besar. Data yang ada menunjukkan bahwa mayoritas pengrajin (73 $\%)$ memperoleh dari lahan sendiri dan dari orang lain sebanyak (23 \%).

\section{Bauran Pemasaran dan Volume Penjualan Gula Merah (Saka) Rakyat}

\section{Produk}

Pada bentuk gula merah tebu ini, produsen menggunakan cetakan tempurung kecil yang sebelum digunakan dibersihkan dan direndam di dalam baskom berisi air untuk menjaga kebersihan cetakan. Cetakan ini berukuran 3-5 $\mathrm{cm}$. Warna gula merah tebu ini bervariasi antara produsen ada yang berwarna cokelat terang, kuning, dan merah. Perbedaan warna ini ditemukan berdasarkan hasil wawancara yang dilakukan dengan responden penelitian, yakni produsen gula merah tebu. Berbeda-bedanya warna ini bisa saja diakibatkan kualitas bahan baku yang berbeda atau interpretasi yang berbeda dalam menjawab warna yang dihasilkan bagi masing-masing responden.

Produk memiliki ukuran sesuai dengan cetakannya yakni setengan batok kelapa dengan diameter 3-5 cm. Adapun tekstur gula merah tebu yang dihasilkan responden yakni rapuh, tidak keras, tidak lengket. Namun, beberapa produsen lebih menyukai memproduksi produk dengan tekstur keras. Adapun kemasaan yang digunakan untuk membungkus gula merah tebu untuk pengangkutan yakni karung dan plastik.

Produk gula merah tebu memiliki rasa manis, seperti asli manis tebu. Produk gula merah tebu ini memiliki ketahanan yang berbeda-beda menurut produsen. Produk paling lama memiliki ketahanan hingga 12 bulan, sedangkan rata-rata produk memiliki ketahanan 3-6 bulan dan ada juga yang memiliki ketahanan hanya 1 bulan. 


\section{Harga}

Harga gula merah tebu yang ditawarkan oleh masing-masing produsen termasuk terjangkau dan sesuai dengan produk yang dihasilkan, baik dari segi ukuran, rasa, bahkan warna produk. Harga produk dapat berubah-ubah setiap saatnya, tergantung keadaan pasar dan musim. Harga yang ditawarkan oleh produsen berbeda pada tiap-tiap produsen berkisar antara Rp 10.000 sampai Rp 15.000 per kilogramnya. Harga yang variatif ini disebabkan berbedanya faktor pertimbangan penentuan harga oleh masing-masing produsen yakni sebagian menetapkan berdasarkan biaya produsi, ada juga yang menetapkan berdasarkan harga pesaing dan terakhir berdasarkan kepada daya beli konsumen. Sistem pembayaran yang diterima oleh seluruh produsen yang menjadi responden yakni pembayaran tunai. Ini dilakukan untuk menjamin produksi yang berkelanjutan, karena penerimaan dari hasil penjualan produk akan digunakan untuk menutupi biaya produksi selanjutnya.

\section{Tempat/Distribusi}

Produk gula merah tebu yang diproduksi oleh responden dalam penelitian ini dipasarkan di beberapa pasar tradisional yang ada di Sumatera Barat, khususnya Kabupaten Tanah Datar. Pasar yang biasanya memasarkan produk gula merah tebu ini adalah Pasar Sinayan, Pasar Tabek Patah, Pasar Koto Baru, Pasar Padang Panjang dan Pasar Padang. Produk ini didistribusikan menggunakan kendaraan roda 4 dan roda 2 dengan mengantarkan langsung dan ada juga diantarkan ke pengumpul terlebih dahulu. Jarak tiap-tiap lokasi produksi dengan pasar terdekat tempat produk dijual rata-rata $2-5 \mathrm{Km}$ dengan kondisi jalan kebanyakan aspal. Namun, ada juga yang kondisi jalan masih berlubang bahkan bebatuan. Kendala dalam distribusi tidak dirasakan signifikan bagi produsen karena menurut penuturan produsen distribusi sudah lancar karena didukung prasarana jalan yang secara keseluruhan dapat dikatakan baik.

\section{Promosi}

Secara keseluruhan produsen gula merah tebu belum ada upaya yang dilakukan untuk mempromosikan produk. Karena selama ini produk sudah dikenal oleh masyarakat dan sudah menjadi kebutuhan sebagian masyarakat. Kegiatan penyebaran informasi yang selama ini dilakukan sebatas melalui produk yakni warna produk yang menunjukkan kualitas produk. Belum adanya proses membujuk dan media informasi yang digunakan oleh produsen dapat menyebabkan belum luasnya pemasaran produk hingga ke luar provinsi. Ketidakadaan promosi ini seharusnya bisa menjadi target yang harus dilakukan produsen agar memperluas pemasaran dan memberikan jumlah penjualan produk yang meningkat. 


\section{Volume Penjualan}

Volume penjualan yang terjadi dari pemasaran gula merah tebu di lokasi penelitian dilihat dalam 6 (enam) terakhir dari waktu pengambilan data. Dalam hal ini, volume penjualan sama dengan volume produksi karena semua produk yang dihasilkan tidak ada yang tidak terjual. Rata-rata volume produksi dari bulan pertama sampai bulan keenam adalah $198 \mathrm{Kg}, 176,33 \mathrm{Kg}, 203,667 \mathrm{Kg}, 221,8$ $\mathrm{Kg}$, 236,6 Kg dan 211,867 Kg per bulan. Melihat data ini maka dapat disimpulkan bahwa jumlah produksi gula merah tebu mengalami fluktuasi setiap bulannya. Hal ini disebabkan beberapa faktor, antara lain karena kelangkaan bahan baku dan keterbatasan jam kerja produsen dalam melakukan kegiatan produksi. Ratarata produksi per bulan secara keseluruhan adalah 206,768 Kg dan memberikan rata-rata penerimaan sebesar $\operatorname{Rp} 2.776 .333,267$. Jumlah produksi dan harga jual yang diterima produsen adalah faktor yang mempengaruhi jumlah penerimaan. Oleh karena itu, menjamin kuantitas serta kualitas produk dan mampu mempertahankan harga yang sesuai atau mudah dijangkau oleh konsumen adalah kunci untuk memperoleh peningkatan penerimaan.

\section{Hubungan Bauran Pemasaran dan Volume Penjualan}

\section{Hubungan Variabel Produk dan Volume Penjualan}

Hasil analisis hubungan antara faktor bauran produk dan volume penjualan pada produk gula merah tebu di Kabupaten Tanah Datar dengan menggunakan uji Chi-Square didapatkan hasil seperti pada Tabel 3.

Tabel 3. Hubungan Variabel Produk dan Volume Penjualan

\begin{tabular}{|c|c|c|c|c|c|c|}
\hline \multirow{3}{*}{\multicolumn{2}{|c|}{ Variabel }} & \multicolumn{2}{|c|}{ Volume Penjualan } & \multirow{2}{*}{ Jumlah } & \multirow{3}{*}{ P Value } & \multirow{3}{*}{ X hitung } \\
\hline & & Rendah & Tinggi & & & \\
\hline & & $\mathrm{N}$ & $\mathrm{N}$ & $\mathrm{N}$ & & \\
\hline \multirow{4}{*}{ Produk } & Tidel Baik & 6 & 8 & 14 & \multirow{6}{*}{0,003} & \multirow{6}{*}{8,571} \\
\hline & IUAK DaIK & $20,00 \%$ & $26,67 \%$ & $46,67 \%$ & & \\
\hline & Baik & 0 & 16 & 16 & & \\
\hline & Dalk & $0,00 \%$ & $53,33 \%$ & $53,33 \%$ & & \\
\hline \multirow{2}{*}{\multicolumn{2}{|c|}{ Total }} & 6 & 24 & 30 & & \\
\hline & & $20,00 \%$ & $80,00 \%$ & $100,00 \%$ & & \\
\hline
\end{tabular}

Tabel 3 memperlihatkan bahwa responden yang menyatakan produk gula merah tebu dari Kabupaten Tanah Datar memiliki nilai produk yang baik dan menghasilkan volume penjualan yang tinggi sebanyak 16 orang responden atau $53,33 \%$. Hal ini menunjukkan adanya hubungan postitif dari kedua variabel tersebut. Berdasarkan hasil statistik dengan menggunakan uji Chi-Square diperoleh hasil perhitungan, yaitu $X$ hitung $=8,571 \geq X$ tabel $=3,84(\alpha=0,05$, $\mathrm{df}$ $=1$ ), maka terdapat hubungan antara variabel produk dan volume penjualan.

8 | Rina Sari dan Nofialdi, Kajian Hubungan Kebijakan Bauran Pemasaran 


\section{Hubungan Variabel Harga dan Volume Penjualan}

Hubungan antara faktor bauran harga dan volume penjualan pada produk gula merah tebu di Kabupaten Tanah Datar dengan menggunakan uji ChiSquare, maka didapatkan hasil seperti pada Tabel 4.

Dari Tabel 4 dapat dilihat bahwa responden yang menyatakan gula merah tebu dari Kabupaten Tanah Datar memiliki nilai harga yang baik dan menghasilkan volume penjualan yang tinggi sebanyak 17 orang (56,67\%). Hal ini menunjukkan adanya hubungan postitif dari kedua variabel tersebut. Harga yang baik adalah harga yang secara umum mampu dijangkau oleh konsumen dan harga ini mampu memberikan keuntungan untuk produsen. Berdasarkan hasil statistik dengan menggunakan uji Chi-Square yang digunakan untuk mengetahui ada atau tidaknya hubungan antara variabel harga dan volume penjualan gula merah tebu di lokasi penelitian, diperoleh hasil perhitungan ChiSquare yaitu $\mathrm{X}$ hitung $=5,868 \geq \mathrm{X}$ tabel $=3,84(\mathrm{\alpha}=0,05, \mathrm{df}=1)$, maka terdapat hubungan antara variabel harga dan volume penjualan.

Tabel 4. Hubungan Variabel Harga dan Volume Penjualan

\begin{tabular}{|c|c|c|c|c|c|c|}
\hline \multirow{3}{*}{ Variabel } & & \multicolumn{2}{|c|}{ Volume Penjualan } & \multirow{2}{*}{ Jumlah } & \multirow{3}{*}{ P Value } & \multirow{3}{*}{ X hitung } \\
\hline & & Rendah & Tinggi & & & \\
\hline & & $\mathbf{N}$ & $\mathbf{N}$ & $\mathrm{N}$ & & \\
\hline \multirow[b]{2}{*}{ Harga } & Tidak Baik & $\begin{array}{c}5 \\
1667 \%\end{array}$ & $\begin{array}{c}7 \\
732 \%\end{array}$ & 12 & \multirow{3}{*}{0,015} & \multirow{3}{*}{5,868} \\
\hline & Baik & $\begin{array}{c}1 \\
3,33 \% \\
\end{array}$ & $\begin{array}{c}17 \\
56,67 \% \\
\end{array}$ & $\begin{array}{c}18 \\
60,00 \%\end{array}$ & & \\
\hline \multicolumn{2}{|l|}{ Total } & $\begin{array}{c}6 \\
20,00 \%\end{array}$ & $\begin{array}{c}24 \\
80,00 \%\end{array}$ & $\begin{array}{c}30 \\
100,00 \%\end{array}$ & & \\
\hline
\end{tabular}

\section{Hubungan Variabel Distribusi/Tempat dan Volume Penjualan}

Hasil analisa huubungan antara variabel distribusi atau tempat dengan volume penjualan ditunjukkan pada Tabel 5 . Tabel 5 memperlihatkan bahwa responden yang menyatakan gula merah tebu dari Kabupaten Tanah Datar memiliki nilai distribusi/tempat yang baik dan menghasilkan volume penjualan yang tinggi sebanyak 12 orang responden atau 40,00\%. Sedangkan nilai distribusi/tempat yang tidak baik dan menghasilkan volume penjualan yang tinggi juga sebanyak 12 responden atau $40,00 \%$. Hal ini menunjukkan hubungan antara distribusi/tempat dan volume penjualan cenderung sama atau tidak berpengaruh positif. Berdasarkan hasil statistik dengan menggunakan uji ChiSquare yang digunakan untuk mengetahui ada atau tidaknya hubungan antara variabel dsitribusi/tempat dengan volume penjualan gula merah tebu di lokasi penelitian, diperoleh hasil perhitungan Chi-Square yaitu $\mathrm{X}$ hitung $=0,536 \leq \mathrm{X}$ 
tabel $=3,84(\mathrm{a}=0,05, \mathrm{df}=1)$, maka tidak terdapat hubungan antara variabel distribusi/tempat dan volume penjualan.

Tabel 5. Hubungan Variabel Distribusi/Tempat dan Volume Penjualan

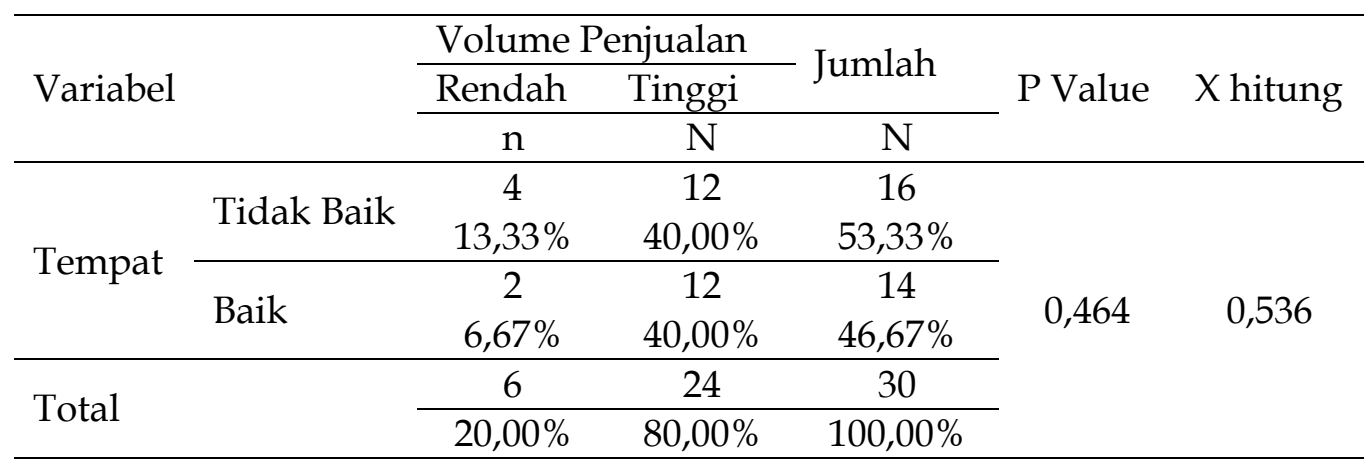

Kebijakan atau strategi bauran pemasaran yang direncanakan dan dilaksanakan oleh produsen sekaligus pemasar, dalam hal ini pengolah gula merah tebu (saka) rakyat di Kabupaten Tanah Datar, akan mempengaruhi volume penjualan dari produknya dan penerimaan yang akan diperoleh. Penilaian produsen terhadap setiap variabel bauran pemasaran (produk, harga, ditribusi/tempat, promosi) yang dilaksanakan, dan seharusnya juga dapat dikendalikannya, akan mengarahkan ke perilaku yang baik seperti yang diharapkan. Misalnya, penilaian terhadap produk yang dihasilkan baik, maka produsen memang akan berusaha menghasilkan produk yang baik. Demikian juga, jika harga yang ditetapkan dinilai baik, yaitu terjangkau oleh konsumen dan menguntungkan bagi produsen, maka harga jualnya akan terjangkau dan kompetitif. Hal sama juga akan berlaku terhadap dua variabel yang lain, yaitu distribusi/tempat dan promosi. Dapat dikatakan bahwa penilaian yang baik akan melahirkan perilaku yang juga baik. Dari praktek bauran pemasaran yang baik akan berpengaruh terhadap persepsi dan sikap konsumen sehingga dapat diharapkan terjadi peningkatan volume penjualan dari waktu ke waktu.

Tetapi, dari hasil analisis hubungan variabel bauran pemasaran dan volume penjualan gula merah (saka) yang sudah dilakukan diperoleh hasil bahwa variabel distribusi/tempat tidak ada hubungan dengan volume penjualan. Demikian juga, variabel promosi tidak dianalisis dalam penelitian ini karena memang tidak dilakukan oleh produsen. Keadaan ini mungkin belum berpengaruh terhadap produksi dan penjualan saat ini, tetapi dengan perkembangan pasar yang semakin kompetitif keadaan bisa berubah. Untuk itu diperlukan penelitian-penelitian lanjutan yang berkaitan. 


\section{SIMPULAN DAN SARAN}

\section{Simpulan}

1. Pengolah gula merah (saka) rakyat di Kabupaten Tanah Datar berproduksi secara tradisional, termasuk usaha kecil dengan tenaga kerja 2-4 orang, menggunakan modal investasi sebesar Rp 20-30 juta dan modal operasional sebesar lebih kurang Rp 100.000, dengan produksi sebanyak 10-20 kg setiap berproduksi. Produk yang dihasilkan dicetak dengan tempurung kelapa kecil (diameter 3-5 cm), dengan warna coklat terang, kemerahan, dan kekuningan, serta tekstur tidak keras dan tidak lengket. Produk dijual dengan harga $\mathrm{Rp}$ 10-15 ribu per kg, diantarkan langsung ke pasar-pasar atau ke pengumpul terlebih dahulu. Sejauh ini, upaya promosi belum dilakukan.

2. Hasil analisis Chi-Square menunjukkan terdapat hubungan volume penjualan dengan variabel produk dan variabel harga, sedangkan dengan variabel distribusi/tempat tidak berhubungan.

\section{Saran}

1. Produsen disarankan mulai memikirkan upaya-upaya promosi agar produk lebih dikenal dan dapat memperluas pasar.

2. Walaupun variabel distribusi/tempat tidak berhubungan dengan volume penjualan, diharapkan ke depannya produsen lebih memperhatikan tempat produksi, misalnya meningkatkan kebersihannya dan memasang tanda atau plang nama sebagai penanda identitas usaha.

\section{DAFTAR PUSTAKA}

BPS. 2015. Kabupaten Tanah Datar dalam Angka. Badan Pusat Statistik Kabupaten Tanah Datar. Batu Sangkar

Felycia Tiera Kencana, Ketut Sukiyono, dan Bambang Sumantri. Analisis Pola Dan Resiko Usaha Gula Aren Di Kabupaten Rejang Lebong. Jurnal AGRISEP. 11(1): 1 - 11.

Kementerian Pertanian. 2014. Outlook Komoditi Tebu. Pusat Data dan Sistem Informasi Pertanian, Sekretariat Jenderal Kementerian Pertanian. Jakarta. hal $18-19$

Kotler, Philip dan Gary Amstrong. 2014. Prinsip-prinsip Pemasaran. Edisi Keduabelas Jilid Dua. Terjemahan oleh Bob Sabran. Penerbit Erlangga. Jakarta. 366 hal.

Mugiono, Sri Marwanti, dan Shofia Nur Awami. 2014. Analisis Pendapatan Usaha Gula Merah Kelapa: Studi Kasus Di Desa Medono Kecamatan 
Kaliwiro Kabupaten Wonosobo. MEDIAGRO; Jurnal Ilmu - ilmu Pertanian. 10(2):22 - 31.

Syahza A. 2005. Paradigma Baru: Pemasaran Produk Pertanian Berbasis Agribisnis Di Daerah Riau. Jurnal Ekonomi, TH. VIII/01/Juli/2003, PPD\&I Fakultas Ekonomi Universitas Tarumanagara, Jakarta. 